\title{
The Contract-labour Photographs of Gunnar Lundh. A Media History Study of a Photo Archive in Motion
}

\author{
By \\ Maria Bäckman
}

\begin{abstract}
The focus of this article is the work of photographer Gunnar Lundh, specifically the works collectively known as the statare photographs, images of rural contract labourers (or statare) that form part of a collection donated to the Nordic Museum in 1961. An overview of how these photographs have circulated in the Swedish public sphere indicates that three areas are particularly suitable for a targeted study of their use and reuse: i) social reportage, aimed at the miserable conditions facing these agricultural labourers in the emerging welfare state; ii) a biographical theme, in which the contract-labour photographs are part of a historical layer that repeatedly connects the author and opinion former Ivar Lo-Johansson with the 'contract-labour photographer' Lundh; and iii) how the older images remain a relevant element of a contemporary material cultural-heritage creation. In all of these examples, Lundh's contract-labour photographs function as visual models through which it becomes possible to represent the contract labourers' historical reality in books, buildings and interiors. However, they also constitute important components in the creation and perpetuation of what this article highlights as a distinctive set of intra-referential memory.
\end{abstract}

Keywords: Photography, Archive, Media history, Intra-referential memory, Contract-labour, Gunnar Lundh, Ivar Lo-Johansson.

Bäckman, Maria: "The Contract-labour Photographs of Gunnar Lundh. A Media History Study of a Photo Archive in Motion", Culture Unbound, Volume 12, issue 1, 2020: 36-64. Published by Linköping University Electronic Press: http://www.cultureunbound.ep.liu.se 


\section{Introduction}

Thanks to the major donation to the Nordic Museum in 1961, the work of photographer Gunnar Lundh is almost uniquely well-documented. In all, the museum has some 300,000 photographs by Lundh in its archive. As a young photographer in 1920s Berlin, Lundh came into contact with the new photographic techniques made possible by $35 \mathrm{~mm}$ compact cameras. The small, handy camera manufactured by Leica allowed him to shoot in the moment, both in the city and the countryside. Although people were often the focus of these images, everyday chores are also a constant presence. The photographs preserved in the archive are often in the form of series, with identical or similar motifs varying in quality. Gunnar Lundh was a working photographer from the 1920s until his death in $1960 .^{1}$

This article discusses Lundh's contract-labour photographs with an emphasis on how this body of images has circulated and been re-mediated in diverse contexts, by different stakeholders and for a variety of purposes. This reasoning links to recent history-of-media research that argues for the need for a broader, cultural-history influenced concept of media (Ekström 2004: 16 et seq.; Jülich, Lundell \& Snickars 2008: 12 et seq.; Cronqvist, Lundell \& Snickars 2014: 13 et seq.). In several concrete studies conducted in the field, media's materiality and pathways have also been granted considerable space (see, for example, Andén-Papadopoulos 2008; Gustavsson 2013; Nyblom 2014; Jülich 2015, as well as Ekström in this issues). It is this expansive media concept that constitutes the theoretical background for the following study of the origin, use, attraction and circulation of the contract-labour photographs.

As far as Lundh is concerned, there can be no doubt that the manageable compact camera verified media historian Anders Ekström's observation that the introduction of new means of representation, "opens the world up in a new way, introducing new possibilities for and limitations to how we arrange and display the world" (Ekström 2008: 43). However, the increased accessibility afforded by these new cameras in comparison to their more cumbersome predecessors not only widened the photographer's radius of action, it also improved their ability to identify possible motifs (cf. Rittsel \& Söderberg 1983: 261, 270 et seq.). The Leica made other images possible to capture, opening the way for another kind of photographic vision. With its significantly cheaper film, this new technique also allowed the photographer to take a great many more pictures.

One overarching question posed by the Nordic Museum's project Images and Stories of Everyday Life-which provides the framework for several of the texts in the current issue of Culture Unbound-deals with finding methods that pave the way for exploring larger pictorial collections of the type represented by the Nordic Museum's Lundh collection. The intention is therefore to conduct both empirical 
observations of the material in question and to use it as a basis for formulating more far-reaching analyses of the photographs, the collection and the archive as an institutional environment. In this sense, the project joins the broader discussion on photography as a source of knowledge regarding historical conditions, as well as a visual tool that individuals and groups have been able to utilise to achieve various goals in their own era.

For reasons that will be explained in greater detail later in the article, I have chosen to focus on Gunnar Lundh's images of contract labourers and farm workers, consisting of approximately 2,000 photographs. ${ }^{2}$ Even now, however, it can be noted that it is these photographs of contract labourers, mostly taken during the period 1937-1945, for which he has subsequently come to be best known. Neither is it insignificant that he took the majority of these photographs in collaboration with author and opinion former Ivar Lo-Johansson.

\section{Who were these Contract Labourers?}

Contract labourers were agricultural workers employed year-round, primarily in southern Sweden and the Mälaren Valley from the mid-eighteenth century until the system was abolished in $1944-45 .^{3}$ Until as late as 1926 , Swedish contract labourers were subject to a series of Servant Acts. They had one week off (known as slankveckan) at the end of October between annual periods of employment, during which the contract labourer could change their job or employer. Their wages were largely paid in kind, in the form of accommodation, food (such as milk, potatoes, rye, wheat, peas), as well as a small sum of money. Unlike farm workers and milkmaids, contract labourers were generally married with families. Their contract often included the services of their wife, for example in milking cows. The population of Sweden increased dramatically during the nineteenth century. This was especially true of those without property, and the economic chasm between the landless and landowners widened at the same time as the desire grew at central government level to rationalise the agricultural sector. As a result of this confluence of events, the number of contract labourers also increased during the nineteenth century, reaching its highest level at around the turn of the century, when the group consisted of 41,900 individuals. By 1943, a couple of years prior to the abolition of the system, the number of contract labourers was calculated at $16,700 .{ }^{4}$ Although similar organisational forms have existed in other countries, this combination of year-round employment and extensive payment in kind (including accommodation and assumed marriage) gave the Swedish contract labourer a special character from an international perspective. Finally, the Swedish contract-labour system is distinguished by its institutionalised form and the fact that it survived in large-scale agricultural production until the end of World War II (Lundh \& Olsson 2008: 14 et seq.). 
By the end of the nineteenth century, contract labourers and the contract-labour system were increasingly seen as an anachronistic remnant of the past. Living in a strictly patriarchal environment, they were also late in unionising, only doing so as the system was dissolved to be replaced by a cash economy. Compared to almost all other groups of workers in society, they had limited freedoms and lived in substandard conditions. Thanks to the authors that came to be associated with them-primarily Ivar Lo-Johansson, Moa Martinsson and Jan Fridegård-during the first half of the twentieth century, the contract labourers became a heavily symbolic literary motif.

The most widely disseminated of the contract-labour photographs look something like this; in brief, they are generally represented as an agricultural proletariat bordering on serfdom or servitude. Commonly employed on large estates or farms, they worked under harsh, sometimes inhuman, conditions for nothing more than board and lodging. Not only that, but the accommodation provided was cold, cramped and for the most part crawling with vermin.

\section{Gunnar Lundh: The Contract-labour Photographer}

During the early decades of the twentieth century, considerable debate raged concerning the vulnerable situation of the contract labourers. Not least, Ivar Lo-Johansson played his part in the work that, during the 1930s and 40s, finally led to the abolition of the contract-labour system in 1945. His books - both novels and short-story collections-were mass-printed in cheap editions that reached a wide readership and he also wrote pamphlets and debate articles in various newspapers. Among other things, he was a frequent contributor to the Swedish Agricultural Workers' Union's newspaper Lantarbetaren. However, photographer Gunnar Lundh was also a central figure in this work, capturing images and creating a visual, documentary form for the social reportage written by Lo-Johansson. A prominent example is their influential photo reportage book Statarna $i$ bild (Images of the Contract Labours) (1948), to which I will return later in the text.

By trialling various approaches, the project Images and Stories of Everyday Life is intended to inspire new means of exploring existing collections. My own choice has been to focus on the contract-labour photographs that to such a large extent have contributed to retrospectively defining Gunnar Lundh as a photographer. Many of these images can reasonably be described as photographic icons; that is to say, they are part of a severely restricted set of images that are recurrently used to illustrate themes such as contract labourers, agricultural workers, Swedish labour reforms or simply rural life in general (cf. Hariman \& Lucaites 2007; Strandroth 2007: 77 et seq.). 
The donation to the Nordic Museum also includes material from the photo agency Gunnar Lundh ran from his Stockholm home from the mid-1930s onwards. This agency material offers an insight into how Lundh himself categorised his work. However, the almost total lack of explanation of the contexts for Lundh's pictures is a significant obstacle. The only available information often consists solely of the year in which the photo was taken, sometimes the place and, extremely rarely, a note of who or what activity is being depicted. This means that we seldom know the purpose behind Lundh's photographs; did he take the pictures because he had a desire to portray a particular contract labourer, or did he happen to be cycling past when he saw a good subject-his handy compact camera always at the ready?

Even if Lundh's many contract-labour photographs are well-known and widely disseminated, they remain strangely anonymous in the archive. How does one study such contextless and, in that sense, mute photographic material? Can we even say with any certainty what the photographs depict? Is it the contract labourers' existence, that is to say, the day-to-day life of a contract labourer? Or are the photographs actually an expression of artistic vision and, if so, whose? Gunnar Lundh's or Ivar-Lo-Johansson's? Are they an expression of political ambition - or, perhaps, even agitation? Are they images of a stain on Sweden's history? Or simply a photographic representation of what today appears to be disturbingly antiquated and musty living conditions endured during a period of frantic modernisation?

In other words, there are many questions associated with the contract-labour photographs as an archived collection. In fact, it is even difficult to categorise or define what is actually meant by a Gunnar Lundh contract-labour photograph. The first of these pictures was taken in the early 1930s and the last one after the abolition of the contract-labour system in 1945. Certain early images were captured on his own initiative, perhaps while cycling through the districts around the Skåne villages of Arild and Mölle, where he ran photographic studios together with his father and siblings, and worked during the summer, while some are clearly the result of joint reportage expeditions undertaken with Lo-Johansson. Others have been published in other contexts, such as themed issues of the magazines $V i$ (1937) and Folket $i$ Bild (1975: 3) that focused on contract labourers. ${ }^{5}$ So, at least some of the material seems to have arisen directly from paid assignments. Below, I shall initially dwell on one of the images often associated with Gunnar Lundh's work as a photographer of contract labourers.

\section{The First Holiday}

As pointed out in the introduction, one significant feature of the Nordic Museum's Lundh collection is that it seems to contain an almost complete lifetime's worth of photographs. Unlike many other photo collections, here it appears that all of the photographer's images have been preserved, including negatives and contact 
sheets, providing us with access to not only published photos but also to a wealth of material that was not deemed suitable for commercial use. It is also often possible to discern that published photographs are part of a longer series all with the same subject, raising the important issue of selection. With regard to the contract-labour photographs, however, we know very little about the context in which this occurred; was it Gunnar Lundh himself who made the selection or perhaps Ivar Lo-Johansson, or was it an editorial decision prior to the completion of the work in question? One simple example may illustrate the difficulty in linking a photo opportunity to a given author.

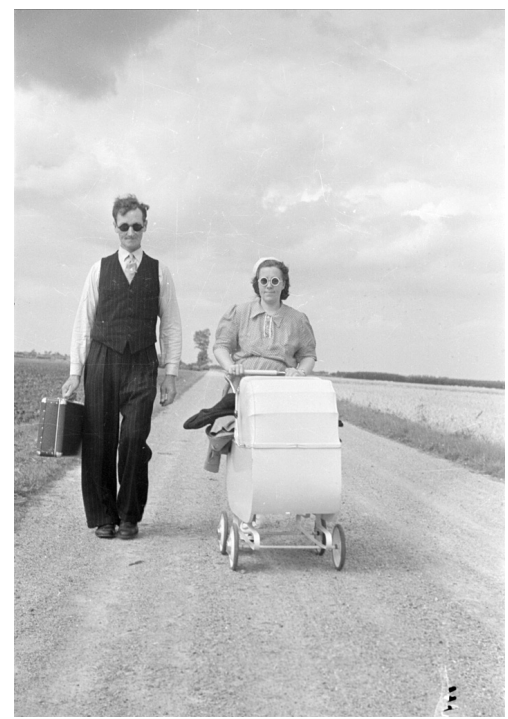

"Den första semestern" (The First Holiday) is one of Gunnar Lundh's most famous photographs. When this is used in historical overviews or other printed/digital media, it is normally said to depict a young couple, contract labourers, on their way home from their first holiday, enjoyed in conjunction with the introduction of statutory paid holidays in 1938 (Rittsel \& Söderberg 1983: 274; cf. enter "semester" [vacation] at Swedish Wikipedia; see also Larsson in this issue). This image of the carefree young couple with a pram wandering along a sunlit gravel road in sunglasses, the man clutching a small suitcase, has thereby come to symbolise the newfound freedom represented by this new statutory leave, not least for agricultural workers, who suddenly found themselves with two weeks of paid annual leave. It appears that, on this sunny summer's day at the end of the 1930s, Ivar Lo-Johansson and Gunnar Lundh happened to catch sight of this homebound couple, happy and rested after what was perhaps their first ever holiday. Gunnar Lundh then captured this iconic image, according to Lo-Johansson upon his own urging. 


\section{Culture Unbound}

Journal of Current Cultural Research

But there is more to be said about the matter, as pointed out by antiquarian and photo historian Eva Dahlman, the photograph was in fact not taken in 1938, but eight years later in 1946. Not only that, by studying the contact sheet that includes the picture, Dahlman was also able to ascertain that it was not a unique image captured in the moment, but rather part of a long series of photographs. The couple had been asked to pose, walk, stand still and walk again before Gunnar Lundh obtained the picture he was looking for (Dahlman 1993).

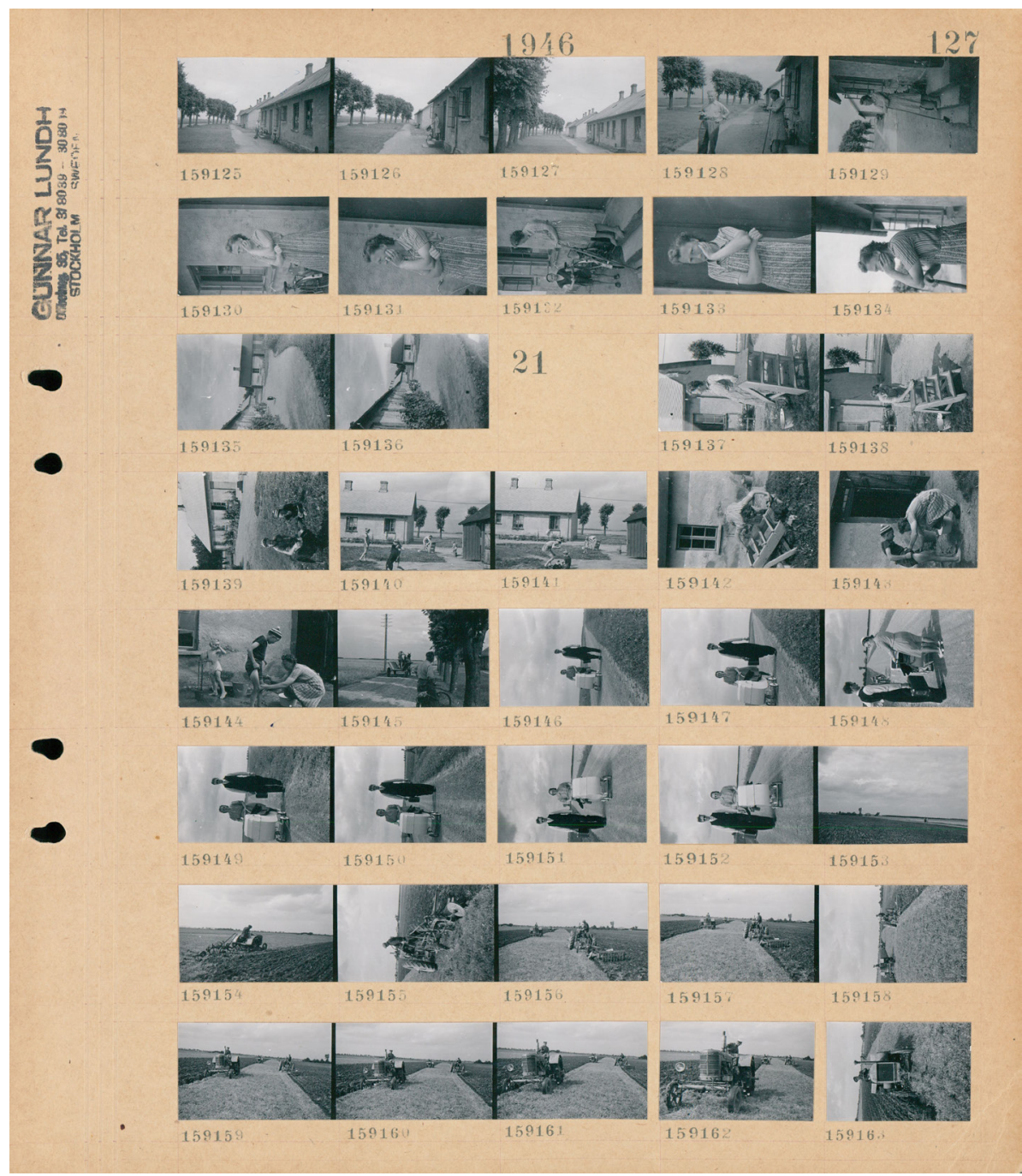


Ivar Lo-Johansson's own written account of the photographing of this relaxed and strolling contract labourer couple is, however, entirely different. In his version, the picture was taken immediately after the 1938 legislation on paid holidays. In his memoir Frihet (Freedom), he describes the bicycle tours of Sweden he undertook with Gunnar Lundh to report on contract labourers. Ivar Lo-Johansson is the first to glimpse the group, apparently making their way home from their holiday. "I just had time to call out to Gunnar Lundh, 'There they are. We threw ourselves from our bicycles and he just managed to take the photograph before they had time to stop" (Lo-Johansson 1985: 269 et seq., quoted by Dahlman 1993).

This dramatic account of the author's immediate insight into the photograph's importance is in stark contrast to the diligence with which the scene was directed in order to obtain the desired motif, as witnessed by the preserved contact sheet. It is however worth mentioning that Gunnar Lundh's famous photograph of the first holiday has been highlighted as either a lucky accident or the result of Ivar Lo-Johansson's sharp gaze. As Dahlman points out, this probably say something about how we value the work of photographers and other image creators in relation to text producers. Here, one could add that the episode also function as a strategic means to strengthen the image of Lo-Johansson as a man of many virtues, among them the capability to successfully extract an iconic picture out of a lazy afternoon.

If nothing else, this example demonstrates the importance of also studying the image's photographic origin. Although the photographs seldom give away any specific information about themselves, they can still provide us with useful knowledge. In fact, this is among the greatest benefits of the donated collection; because the original contact sheets, often with fully preserved series of photos, are available digitally in the Nordic Museum archives, it is unusually fertile ground for examining the more work-oriented aspects of Lundh's photography. As in the given example, by studying the contact sheets, Lundh the photographer may be suddenly revealed as possessing a clear directorial vision, while at other occasions he can be seen to exercise a profound sensitivity for capturing spontaneous moments in time (cf. Thorbech 1994: 132; Nilsson 1975: 95, 104).

\section{Circulation and Re-mediation}

In the end, the problem with the material's lack of wider context proved to be far from limited to a shortage of concrete information regarding its subjects, dates and purposes; it long appeared that the 'contract-labour photographer' Gunnar Lundh himself did not consider this group to be particularly relevant to his own craft. In Lundh's photo-agency material, carefully categorised and filed, often into subcategories (cf. Nilsson 1975: 94, 104), contract labourer is not even a category in its own right. However, after closer examination, a colleague and I identified 
individual images from the photobook Statarna i bild under the heading Agrarian. These could show up under categories and subcategories such as Ploughing, Oxen, Women, etc. Finally, we came across an archive box in which Lundh had collected his contract-labour photographs under the subcategory Agrarian: Agricultural labourer: Contract labourer. This is where he himself had chosen to place the pictures, interspersed with the subcategories Agrarian: Cowshed, Agrarian: Reapers and Agrarian: Milking Centre.

Given the lack of clarity with regard to the contract-labour photographs' complicated and drawn-out origins, I concluded that the only available opportunity to approach the collection lay in taking a step back. Instead of viewing the photographs as in-the-moment documents, it seemed considerably more rewarding to study the contexts assigned to them retroactively. This is similar in approach to Solveig Jülich's (2015) interest in another, more internationally renowned, Swedish photographer, Lennart Nilsson. Based on a thorough documentation of photographic material, photo sessions, assignments, publications and existing economic and publishing networks, Jülich has, among other things, followed the national and international circulation and re-mediation of Nilsson's photobook A Child Is Born.$^{6}$ For obvious reasons this method is linked to both what Appadurai and others have put forward as writing the social biography of objects (Appadurai 1988; cf. Mintz 1986) and the extensive research conducted over recent years based on various types of shadowing (see, for example, Latour 1988; Czarniawska 2007).

A further analytical point of entry to the place assumed by the contract-labour photographs in the public sphere is to research the selection processes prior to publication or other forms or re-mediation. Here, I would especially like to emphasise Leila Koivunen's (2009) discussion of the central role of the illustration in nineteenth-century British (written) travel accounts. Far from being involved in the same kind of colonial project, Gunnar Lundh's contract-labour photographs can nevertheless be likened to a somewhat similar documentary breakthrough into then relatively unknown and unexplored territory. Moreover, as we will see, the nexus of text and picture/photograph is very much a relevant factor when it comes to how the photographs have been circulated over time.

Based on a cohesive focus on the selection, use and dissemination of the contract-labour photographs, I have identified three areas that are, in my opinion, suited to targeted study of their use and reuse. First, there is the social reportage; second, we have a biographical theme; and third, there is the question of how the older images maintain their relevance through inclusion in a contemporary material cultural-heritage creation. In the latter context, Lundh's contract-labour photographs function as visual representations in an attempt to use buildings and 
interiors to capture the historical reality of the contract labourers' way of life. As we will see, the content and themes from these areas often move fluidly between categories.

\section{The Contract-labour Photographs and Social Reportage}

The initial and well-known impact was that the contract labourers, through social reportage, became part of the Swedish labour movement's struggle to create a socially sustainable folkhem, or home for the people. Against this background, the contract labourers constituted a problematic but useful example of a group that was yet to be included in the modern, forward-looking welfare efforts being made in the 1930s and 40s. In other words, images of the poverty endured by the contract labourers could be used to illustrate the need for political reform to improve the lot of a neglected social group (Hassner 1970, 1977; Nilsson 1996: 158). Like earlier documentations of the slums of Victorian London and the thirties Dust Bowl of the depression-era United States, Gunnar Lundh's images of Swedish contract labourers became a photographic tool for revealing the everyday misery in which many of the folkhem's inhabitants still lived (cf. Strandroth 2009). The photographs did more than simply describe or depict, they also demanded political action. Lundh's contract-labour photographs can therefore undoubtedly be incorporated into the documentary and critical photographic tradition
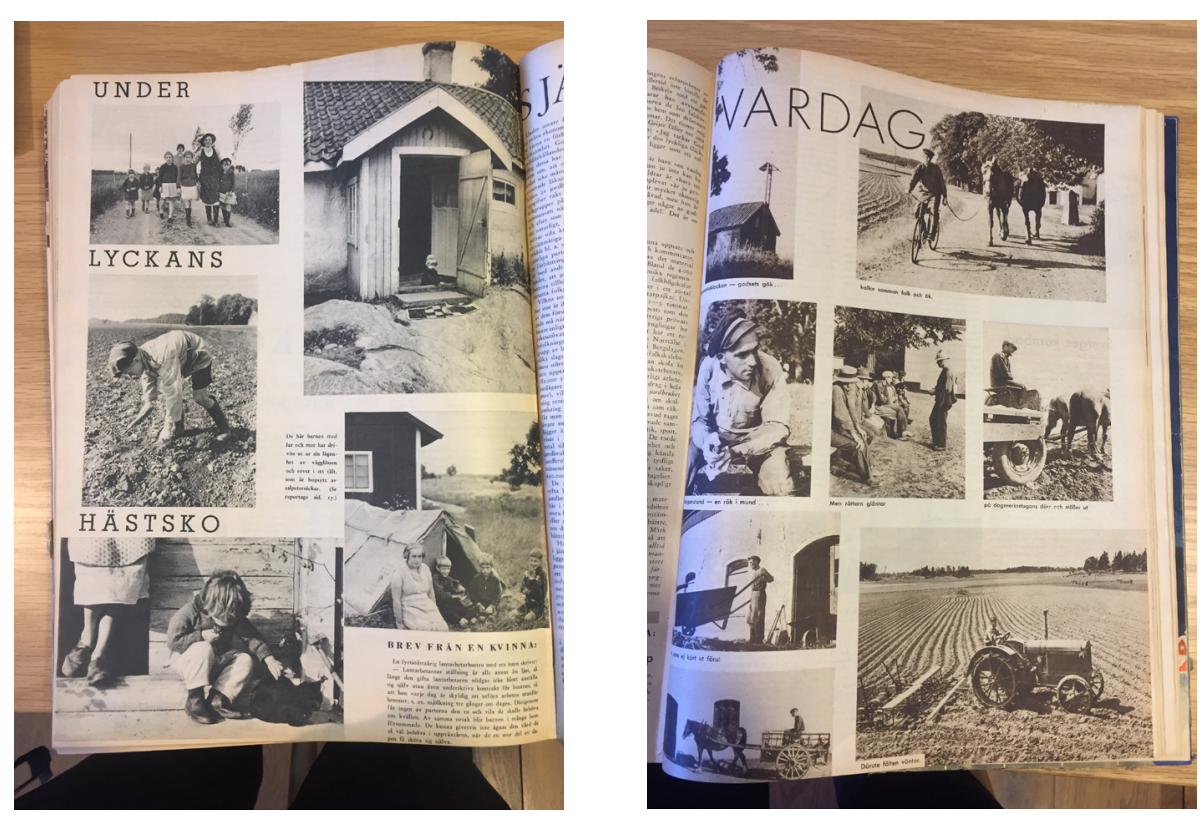
established in the US by the FSA Photographers. ${ }^{7}$ To no surprise, some examples of Gunnar Lundh's contract-labour photographs have been compared to Dorothea Lange's famous 1936 image "Migrant Mother" (Thorbech 1994; Gullers 2012).

In order for the contract-labour photographs to be truly effective, it was, however, necessary to furnish them with both text and context. As Roland Barthes (2007 [1970]) emphasises, the ambiguous nature of the images requires that they are provided with textual markers if they are to convey their intended meaning. The reportage published in $V i$ in 1937 can be seen as an example of how text and image collaborated to convey a clear message about the precarious position of the contract labourers to the magazine's readership. The photographs in these reports function either to illustrate articles dealing with the poor conditions under which the contract labourers lived (for example by showing and discussing inadequate housing), or to provide an insight into their everyday lives (in the form of photospreads with very brief explanatory texts).

It is this close connection between text and image that was further developed a decade later, when Lundh's documentary photographs and Lo-Johansson's social-realist descriptions of the contract labourers' existence came together in the photobook Statarna i bild (1948). The text in the photobook is allowed to expand beyond the limits imposed by the Vi photospreads without in any way dominating the photography. Lo-Johansson himself commented that his preferred method as a writer was to work through what he called social poetry: "Literature belongs to society. It is not imposed on society. This tendency is the morality of poetry" (Quoted from Reberg 2001:51). ${ }^{8}$ It is exactly this social tendency-i.e. its strategic choice of descriptions, narrative motifs and touching illustrations-that forms the basis for the visual design of Statarna i bild (cf. Dahlman 1993).

For those with access to the Nordic Museum's extensive collection of Lundh's photographs, it is obvious that the photographs published in the book represent a conscious choice intended to highlight certain aspects while excluding others. Therefore, in the photobook, there is little space for the joy, relaxation, larks and games to which the collected pictorial material in the archive also bears witness (cf. Hellspong 2004: 286f). It is not difficult to discern the presence of two people and two personalities; on one hand, the snapper Gunnar Lundh with his interest in day-to-day activities and proven ability to capture those spontaneous moments in flight and, on the other, author Ivar Lo-Johansson with his equally clear conviction of what was required to unequivocally convey the gravity of the contract labourers' hardships.

In years to come there would be a great explosion of photographs used in the growing mass market of picture magazines and the documentary photography book, both in Sweden and internationally. However, when Statarna $i$ bild was 


\section{Culture Unbound}

Journal of Current Cultural Research

published it was still very much a novelty. In fact, it was one of the very first examples of a purely social depiction to appear in photobook form in Sweden and its reception testifies to the fact that the public, to a certain extent, realised that they were witnessing a new phenomenon, although this did not prevent accusations of tardiness against the authors. ${ }^{9}$ In its review, national daily newspaper Svenska
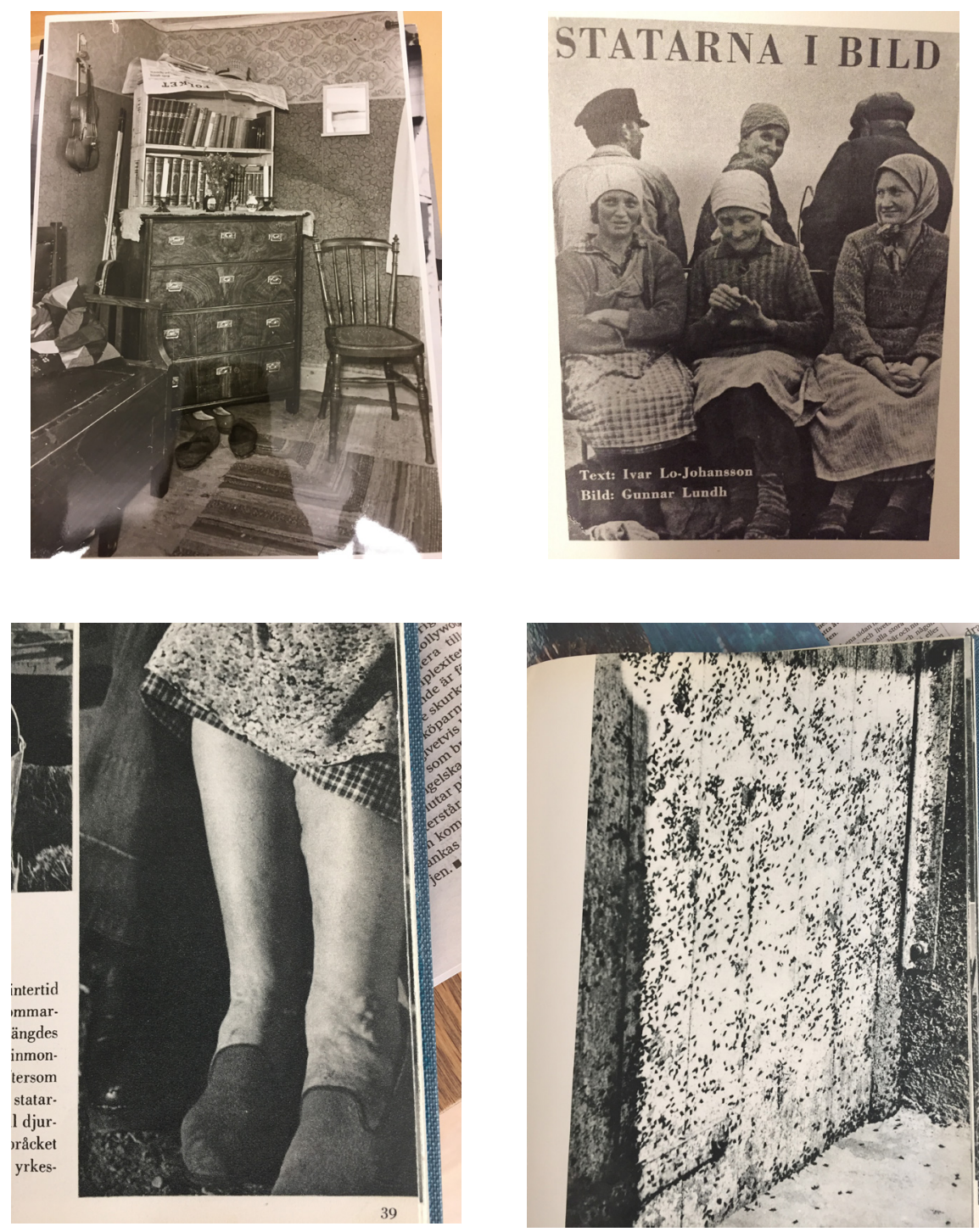

Dagbladet observed that it seemed strange that Lo-Johansson, as engaged as he was in the plight of the contract labourers, had not previously utilised the photographic medium, stating that, "the camera's unadulterated realism would 
have been invaluable in the struggle for contract labourers' rights". Nevertheless, given that it was now 1948 and the contract-labour system was a thing of the past, the reviewer felt that the book was more of a scrapbook of a bygone era. A couple of the photographs-the countless flies on the barn door and a moving wagon overflowing with possessions-were however highlighted as being particularly moving (source: Svenska Dagbladet 23.09.1948).

In retrospect, one can also state that Statarna $i$ bild has had an enormous impact in terms of which of Lundh's contract-labour photographs have continued to circulate and be re-mediated. Among these images, particular mention should be made of the photographs depicting threadbare homes; a bookshelf with a few books (known as the alter of culture); milkmaids; an old woman's varicose legs; the flies; and the creaking moving-cart, as highlighted by the contemporary reviewer.

These photographs recur in a variety of contexts and genres, including: biographies of Ivar Lo-Johansson; scientific articles; commemorative and anniversary texts; popular science journals; and as models for physical environments such as contract labourers' housing conditions or the staging of events such as moving home. The images constitute an illustration of the conditions described in the texts or of the author's contentions. It is nowhere near as common that the pictorial material in question is highlighted as photographic/artistic work in its own right; rather, this generally takes place in relation to Lo-Johansson. One example of a recurring theme is the descriptions of Lundh as Lo-Johansson's companion or photographer, clearly subordinate to the latter's political ambitions and desire for social change.

The contract-labour photographs' association with the social reportage is therefore linked to the rhetorical work that the photographs could perform contemporaneously, when they were relatively freshly taken. In this respect, they differ from how the images remain active in the creation of various retrospective projects. Firstly, one such important context is their use as historical testimony in the forming of the contract labourers as a part of Swedish cultural heritage. In other words, they are utilised as an important pedagogical tool in an ongoing use of the past (Aronsson 2004) with material signatures. Secondly, there is also a distinct biographical trail where the contract-labour photographs are a component of a historical layer that links the author and opinion-former Ivar Lo-Johansson with the photographer Gunnar Lundh and his familiar images of contract labourers. The remainder of this article will dwell on this multifaceted memory work; however, given the relationships between our three empirical fields, folkhemmet, modernity and social structures will inevitably be drawn into the discussion. ${ }^{10}$ 


\section{Mirroring Memories}

"Gunnar Lundh is a concept - the 'snapper' and 'contract-labour photographer' who collaborated with Ivar Lo-Johansson." These are the words that introduce a review of Gunnar Lundh's work in the Nordic Museum's yearbook Fataburen (Thorbech 1994: 124). It is with remarkably similar wording that Lundh is introduced in Den svenska fotografins historia (A History of Swedish Photography): "Gunnar Lundh (1898-1960) is primarily known as Ivar Lo-Johansson's photographer. Together, they conducted reportage that contributed to the abolition of the contract-labour system in 1944" (Rittsel \& Söderberg 1983: 270). Neither is there any doubt that Lundh the photographer is primarily associated with the contract-labour photographs that he published in collaboration with Lo-Johansson. However, as stated above, the reverse is also true.

Lo-Johnsson is usually claimed as one of the more powerful influences on the wave of public opinion that led to the final abolition of the contract-labour system in 1945 (cf. Furuland 1976: 190 et seq.; Oldberg 1964: 33 et seq.). To a large extent, it is also his literary, social-realist descriptions-the latter to a significant degree combinations of Ivar Lo-Johansson's texts with Gunnar Lundh's images-that have come to colour posthumous perceptions of the conditions that characterised the day-to-day lives of contract labourers. Lo-Johansson too can therefore be seen to be intimately associated with the contract labourers, the contract-labour system and, not least, with many of the photographs of various contract labourer environments taken by Gunnar Lundh in order to give visual form to Lo-Johansson's words. This close connection is noticeable in the manner in which the contract labourers, Lo-Johnsson and Lundh form a recurring triad in biographical or narrative contexts relating to the contract labourers and the contract-labour system, the photographer Gunnar Lundh or the author and debater Ivar Lo-Johansson.

In both informative, biographical and academic context, the contract labourers and/or the contract-labour system are generally described using visual aids in the form of Gunnar Lundh's photographs and with reference to Ivar Lo-Johansson's literary reform efforts. In the same way, it is convenient to refer to Lundh as the contract-labour photographer, while any biography of Lo-Johansson would be deemed incomplete without his role as the public voice of the contract labourers. Conversely, recollections of author and opinion-former Lo-Johansson are often linked to his efforts on behalf of the contract labourers, often illustrated by a photograph taken by Gunnar Lundh. Irrespective of the direction from which one approaches, all of the component parts of this triad are illuminated. In this sense, the contract labourers, Gunnar Lundh and Ivar Lo-Johansson can be viewed as a distinctive set of collective and intra-referential memory. That is to say, they are so tightly intertwined with each other that the pure mentioning of one of 
them inevitably evokes associations to the other ones. The concept of mirroring memories thus underlines that we are facing a multi-mediated memory work that encompasses and unites several different parties.

Lundh's entry in the Dictionary of Swedish National Biography (written by ethnologist Bo G. Nilsson) therefore quite rightly gives a prominent place to his association with the contract labourers and Lo-Johansson:

L was a socially observant photographer. His pictures of the Swedish countryside with men and women engaged in agricultural labour are well-known and in his depiction of the living conditions of contract labourers there are images that approach classic status. He has produced four photobooks. The book Statarna $i$ bild-undoubtedly his most important-was published in 1948. This documentary photo collection is the result of a fruitful collaboration with Ivar Lo-Johansson, author of the book's text. The book was issued at the time of the Swedish Agricultural Workers' Union's 30th anniversary. Since 1937, Ivar Lo-Johansson and L had undertaken reportage assignments in contract labourer provinces on behalf of a number of magazines.

The same applied when, in 1975, the Nordic Museum collaborated with Sveriges Radio on a joint 30th-anniversary publication to mark the abolition of the contract-labour system. Even in this commemorative publication, titled Statare. Statarklassens historia $i$ ord och bild till 30-årsminnnet av det sista statarlasset (Contract labourers-the history of the contract-labour class in words and pictures) (Furuland 1975), the preface returns to the combination of Gunnar Lundh, Ivar Lo-Johansson and the contract labourers:

The photographs are mostly the work of Gunnar Lundh, taken on his travels during the 1930s and 1940s with Ivar Lo-Johansson, who drew his attention to the importance of documenting the lives and conditions of the contract labourers.

So, Gunnar Lundh is not only a significant part of the common cultural memory and the representation of the contract labourers, he is also a participant in the representation of Ivar Lo-Johansson as the 'contract-labour author' (see also Reberg 2001: 22, 50). Those biographical presentations that emphasise the author's intimacy with the contract labourers as both a personal and political project are generally illustrated by a Lundh photograph, preferably depicting the pugnacious author standing in front of a moving cart, a farm labourers' cottage or astride a bicycle on his way to investigate the contract labourers' living conditions. It is hardly an understatement to say that these recurring images formed part of Lo-Johansson's early efforts to recreate himself as his own brand (cf. Liljestrand). 
Culture Unbound

Journal of Current Cultural Research
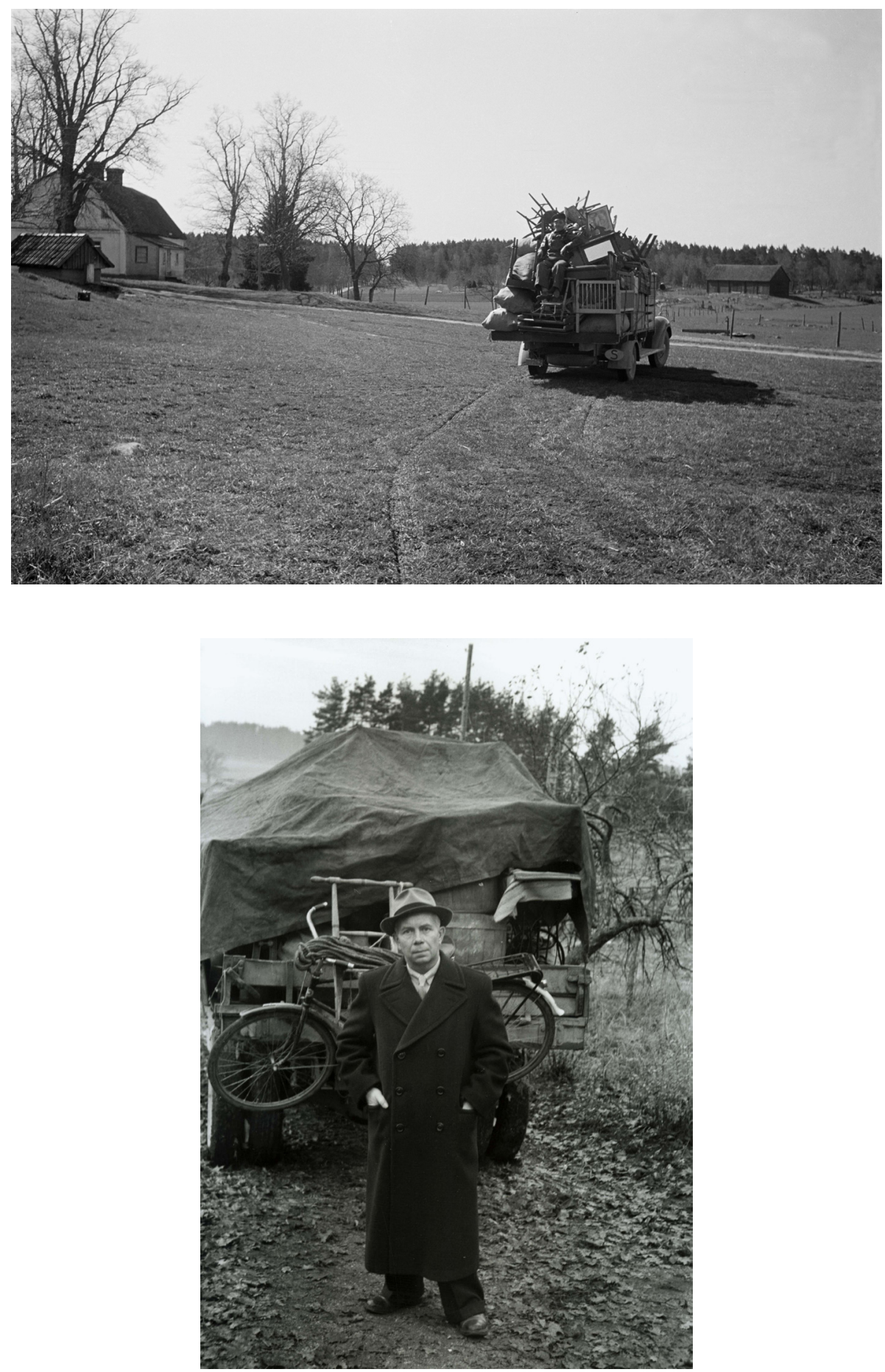
It is in this and similar ways that the intra referential memory continues to be constituted, reasserted and perpetuated with the aid of various printed media and genres. The active memory work is not, however, limited to words and images; it can also be traced through various built and staged environments in which it is part of an active creation of cultural heritage. Here, too, the close association between 'contract-labour photographer' Gunnar Lundh's iconic images, 'contract-labour author' and debater Ivar Lo-Johansson, and the contract-labour system and the contract labourers themselves is reaffirmed time and time again. In this materialisation, it is possible to follow how the contract-labour photographs now to a large extent live a life of their own away from the archival and literary models.

\section{The Berga Farm Labourers' Cottage}

There is a red farm labourers' cottage with white window frames in Skansen (Stockholm), the world's first open-air museum, consisting of two single-room homes with a common hallway and a larder for each family. The present location of the small house is due to a decision taken by the Nordic Museum and Skansen on the abolition of the contract-labour system, that it would be desirable to preserve an authentic farm labourers' cottage (Berg 1975: 5). ${ }^{11}$ Mats Rehnberg, then a curator at the Nordic Museum and later a professor of folklore/ethnology, was tasked together with Ivar Lo-Johansson with finding a suitable example. In 1949, a building was identified in the Parish of Åker in Södermanland that could be acquired on condition that the current tenants were allowed to remain for as long as they wished before the house was moved. This condition meant that the building was not finally transported to Skansen until 1966, on the death of the final tenant.

The left-hand home in the cottage was furnished as it was when the Carlsson family lived there between 1874 and 1924. In conjunction with the acquisition to Skansen, the Carlsson's grandchild was interviewed in order to document everything from the family's work and leisure activities to how their single room was decorated. The Carlsson's had only two children and the family never left the cottage, remaining there for fifty years, even after their retirement. According to their grandchild, they enjoyed life on the farm. This is something that is often highlighted by museum pedagogues who work in the cottage as some form of aberration that demands explanation. In the usual accounts of the contract-labour system, including those of Lo-Johansson, contract labourers were likely to have large families and to move on a yearly basis in search of better accommodation or more humane working conditions. The space inside this particular labourer's cottage provides a sense of calm and security, with a high made-up bed, a kitchen sofa that invites tourists to take the weight off of their feet, flowers in the windows, 
a ticking wall clock and a table with paraffin lamp. ${ }^{12}$ However, thanks to several own visits in the milieu, I also know that the fact that many visitors comment that the home seems pleasant and cosy is something the museum staff, when asked, find difficult to deal with; it shouldn't 'really' be pleasant in a farm labourers' cottage.

In clear contrast to this harmonious image of contract labourer life, the other home-which also lacks any link to a living family-is much more in keeping with the accounts of those such as Lo-Johansson, with a sleeping area for multiple children, threadbare furnishings, unwashed porcelain left out and beds with their legs in tins to hinder the progress of bedbugs. This is also the only environment within Skansen that is not kept neat and clean for visiting tourists. Interestingly enough, at least according to the museum staff at work in the cottage when I have been talking to them, it is also this more authentic environment that appears to be comparatively more appealing, as it does not chaff against expectations. Many visitors are taken aback when homeliness contradicts the obvious social misery which they are prepared to encounter when entering a farm labourers' cottage.

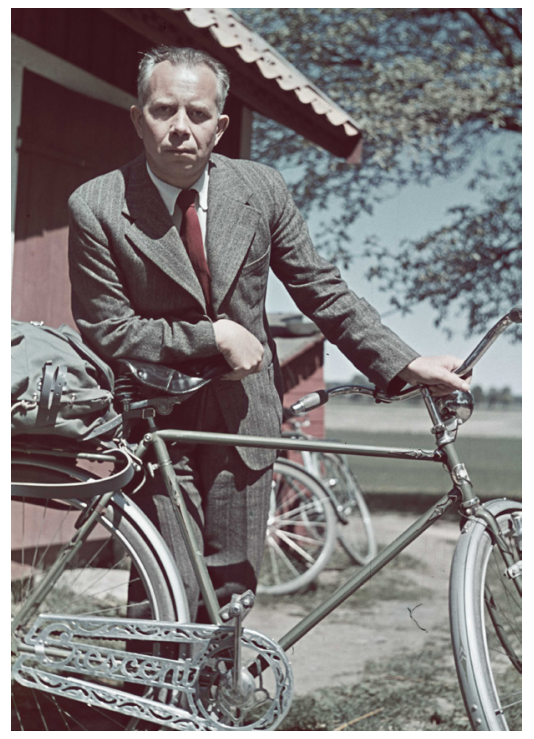

In a somewhat critical review of the image of contract labourers painted by Ivar Lo-Johansson's collected works on the theme, ethnologist Mats Hellspong confirms that it is Lo-Johansson's decidedly negative characterisation of contract labourer life that is usually given material form in museums (2004: 305). ${ }^{13}$ Using a number of examples from the photobook Statarna $i$ bild (1948), Hellspong demonstrates how the black and white photographs in the book are chosen to emphasise the negative aspects of daily contract labourer life. 
The strategic work to influence that forms the framework of much of Ivar Lo-Johansson's writings on contract labourers-and which is accentuated by Gunnar Lundh's social-realist images of women with varicose veins, families with hordes of children, steely-eyed labourers and overloaded moving cartstherefore has many similarities to the highly prevalent black poetry identified by Per-Markku Ristilammi (1994) in his understanding and descriptions of the Swedish million-home housing estates since the 1970s. Even against this background, Ristilammi confirms that this more positive view from the inside becomes somewhat problematical in that it chaffs against the expected representation. This is especially the case if the negative descriptions of the housing estate are at the same time the very catalyst that is expected to pave the way for social intervention and increased resources (ibid: 131f).

\section{Ivar Los Park}

There are, however, contexts in which the light and dark are seemingly permitted to exist side by side. Ivar Los' Park is situated on Bastugatan in Södermalm, Stockholm, directly across the road from the building that houses the two apartments in which Lo-Johansson lived and worked for most of his adult life. ${ }^{14}$ The park is hidden away behind a high red fence with a gate that opens up to reveal a panoramic view across the bay of Riddarfärden and central Stockholm. Aside from trees and shrubs, lawns and benches, the park contains a bust of Ivar Lo-Johansson and a themed playground.

For the purposes of this article, the themed playground is our primary interest. This consists of a number of houses, a barn, a grazing cow with calf, a horse and cart and a tractor; all solid timber constructions with realistic details, such as the leather harness hanging from a nail and the milk churn in the milking shed.

On the City of Stockholm website, you can read that the park has a rural theme, that is to say, the countryside, and that there are existing houses, interiors and a barn to explore. The idyllic, picture-book image of the 'countryside' created in the park is in stark contrast to the harsh rural life about which Lo-Johansson wrote. And yet, the themes given material form in the park's wooden sculptures and constructed interiors are easily recognisable. Here we find a number of markers for contract labourer life that Lo-Johansson and Statarna $i$ bild helped to bring to a wider audience; the animals, the milking and, not least, the tractor-the symbol of the future, of modernity and a beckoning freedom for the contract labourers.

Ivar Los' Park was officially opened in 1990 by former Social Democratic Minister of Finance Gunnar Sträng. In the description of the park, it is stated that Sträng shared the same rural-proletarian roots as Ivar Lo-Johansson, and that in his capacity as chairman of the Swedish Agricultural Workers' Union he contributed 
to driving through the abolition of the contract-labour system in 1945-following the trail blazed by writers engaged in the issue, such as Lo-Johansson ${ }^{15}$. The connection between Ivar Lo- Johansson and the contract labourers was, in other words, already explicit when the park was opened, and was further reinforced by the thematic construction of the playground, despite its idyllic appearance and the fact that the contract-labourer link was never stated.

The official opening of the park by the previous Minister of Finance also reveals one of the other common threads running through the contract labourer issue and the early labour movement. Sträng's own political career, taking him to a position as one of the twentieth century's most successful Social Democratic politician, is in fact part of this context. In 1932, he became an ombudsman for the Swedish Agricultural Workers' Union and was tasked with unionising both agricultural workers and contract-labourers. During the 1930s, he carried out this work by cycling around the countryside in the most contract-labour-intensive areas of Sweden. In 1939, Sträng was elected chairman of the Agricultural Workers' Union, primarily thanks to his ability to get to grips with the Union's financial disarray, although his successful enrolment of large numbers of new members was a contributory factor. This is generally described as a successful period for the Union; membership continued to grow and the working conditions of agricultural workers were significantly improved. In retrospect, Sträng's most acclaimed achievement in trade unionism appears to have been his participation in the abolition of the contract-labour system. During this period, Sträng came to the attention of the Social Democrats and the Swedish Trade Union Confederation and in 1945 he was given a ministerial post. Sträng's entry in the Dictionary of Swedish National Biography (authored by historian Anders L. Johansson) specifically states that it was the successes achieved by the Agricultural Workers' Union under Sträng's chairmanship that led to the perception of him as a rising star within the party.

\section{Images on Route}

Today, there is a noticeable ambition among a number of researchers to present a more nuanced picture of the contract labourers than the starkly negative image that is to a great extent supported by the combination of Ivar Lo-Johansson's words and Gunnar Lundh's photographs. Established notions such as the white whip' (for women's demanding daily milking work), 'horizontal tower blocks' (for the terraces of labourers' cottages) and the endless moving between jobs and homes; these all belong to the older estates and attempts are currently underway to break them down and reveal their complexity (cf. Hirdman 2012: 58). In the introduction to the book Herrgårdsromantik och statarelände (Manor House 
Romance and Sharecropper Misery) (2004: 17 et seq.), Karin Lindvall writes that the manor house environment has long been depicted in "dark colours" in newspaper articles and books dealing with issues related to farm labourers and contract labourers, highlighting the novels of Jan Fridegård and Ivar Lo-Johansson as the culmination of this period. According to Lindvall, a common and recurring emphasis on the manor house environment as a strict class society of subservience, oppression, great injustices and antiquated norms has taken its place in history as an undisputable fact. She, however, wishes to remind us that these numerous descriptions were part of a wider political debate that, aside from the issue of contract labourers and their conditions, also dealt with the representation of an overarching social democratic social ideal of welfare and modernity. Others point to the fact that newfangled technologies and industrial collaborations could have major local and regional consequences for the design of the contract-labourer system on the ground (Lundh \& Olsson 2008: 20 et seq.).

Lindvall's point is about how we understand the past. She contends that the images and narratives fashioned by Ivar Lo-Johansson and "his photographic companion" Gunnar Lundh regarding the contract labourers have entered history as "truer than reality and real memories" (ibid: 18). Reservations regarding unilaterally negative depictions of the heterogenous collective that the contract labourers may be said to have constituted mean that the common cultural memory is beginning to creak at the joints. For those who work with the use and reuse of the contract-labour photographs, the question therefore arises of what will happen to Gunnar Lundh's famous images in the future. Will it be possible to incorporate them into this new, critical orientation?

There is much to suggest that this will prove to be the case, which is hardly strange. The Nordic Museum's comprehensive collection of Lundh's photographs contains a wealth of material that has seldom, if ever, been published-for the simple reason that it did not fit snuggly into the overall framework constructed to highlight the privations and harsh realities of contract labourer life. However, as stated previously, the preserved photographs are entirely capable of telling stories about the contract labourers and the contract-labour system other than those to which we have become accustomed. One of the most recent works collecting contemporary research on contract labourers, the anthology Statarna - i myt och verklighet (Contract labourers-In Myth and Reality) (Lundh \& Olsson, ed. 2008), is intended to problematise some of the main features of the accepted view of the contract-labour period in Sweden. Here too, a number of Gunnar Lundh's photographs are used. So, it would be no surprise to find Lundh's pictorial material being recycled in other representations aimed at correcting, nuancing or broadening the "depiction of misery" that has to such a great extent been based on his own photographs. And possibly this will also be the case with many of his 


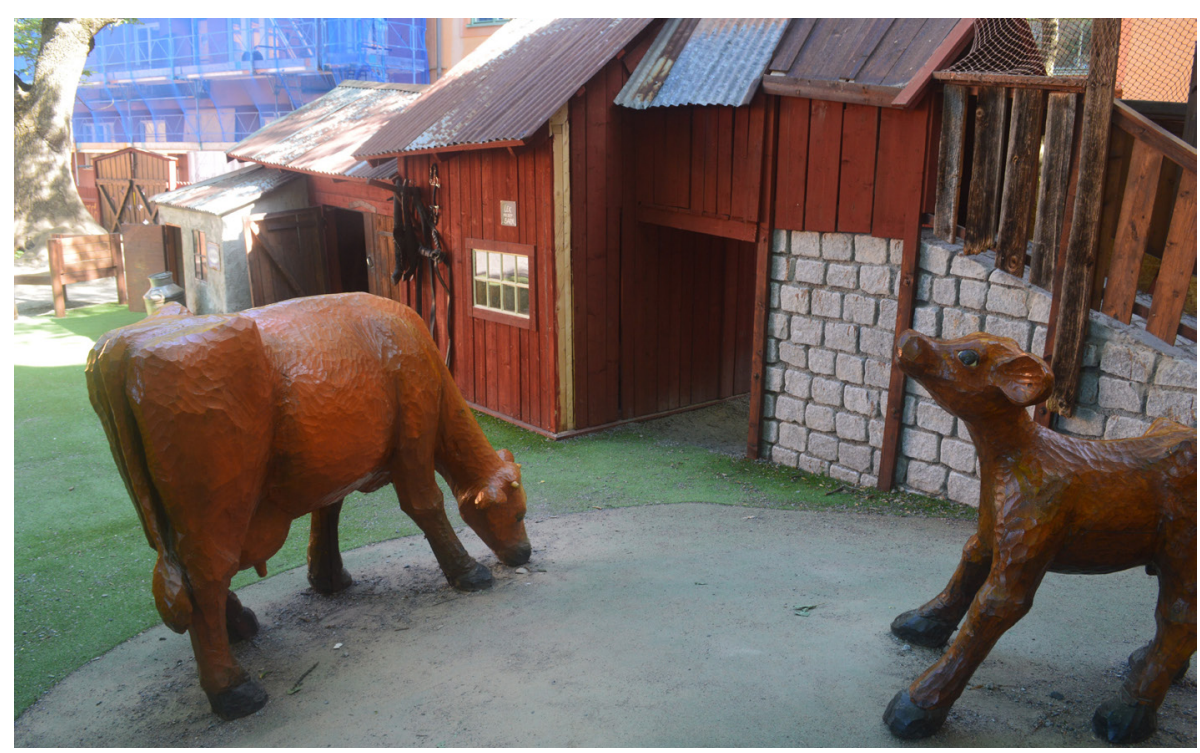

Photographer: Vidar Ekström.

already iconic images; perhaps these too will continue their successful circulation? Despite everything, their message is of course not set in stone in the photographs themselves-it arises in the communicative stream that runs between the pictures, their context and the viewer.

The article could be rounded off with this remark; however, at the same time, the just-mentioned anthology demonstrates that the contract-labour photographs' circulation is unsuited to overly schematic analyses. One of Lundh's photographs used in the book's chapter on contract labourers' housing (ibid: 169), depicting a group of children and youths in front of a white, half-timbered house, can be viewed as a conscious repost to the traditional view so often expressed in reportage published in Vi and Statarna $i$ bild, with its cramped accommodation and shabby interiors. On viewing this rarely published photograph, we find ourselves far from Lo-Johansson's characterisation of terraces of labourer's cottages as "horizontal tower blocks". Other images are less easy to sort according to such a contrasting logic.

The anthology's cover image depicts six people, four women and two men, sitting on what seems to be a horse-drawn cart. The photograph has been captioned: "Contract labourers on their way back from milking. Ven, August 1934. Photo: Gunnar Lundh (Nordic Museum)". One of the women in the picture has a smile playing on her lips, while the others are clearly more reserved. They return the camera's gaze more or less without expression. The thing is, this is the very same photograph that was used on the cover of Statarna $i$ bild. Or, is it really the same picture? A closer examination reveals that these are actually two different 
shots taken at the same time. However, contrary to what one might expect, the cover of the original reportage book bears a noticeably more upbeat and relaxed image of the homebound group than the later history textbook that intends to present a more nuanced view of contract-labourer life.

Once again we can benefit from the preserved contact sheet. The contact sheet containing the series of photographs in question makes it clear that there are not only two similar images but rather a long series. The preserved photographs show six people whose expressions shift greatly along a scale from serious or sombre to relaxed high spirits. This complicates in an interesting manner the choice of image and the social tendency I previously attempted to link to the common cultural memory of Gunnar Lundh, Ivar Lo-Johansson and the contract labourers. What considerations lie behind the two covers? Why, in both cases, has the choice fallen on a photograph that appears to risk the destabilisation of the authors' own message? Was there a desire to avoid the all too obvious or programmatic? Or has whomever was responsible noticed something in the images that has eluded my own examination? So, the article leads us on once again to a number of unanswered questions. And, once again, we can but confirm the presence of the photo medium's always unfinished nature; the permeability that opens it up to varying interpretations and purposes.

Recent efforts from scholars with an interest in documentary photography have been directed toward the possibility to identify and give biographical accounts for the anonymous persons depicted in the pictures. No doubt, such an ambition might restore some of the agency to the "object", at the same time as it challenges the widespread concept of the photographer as the sole creator of the work. Even though, in this specific case, it might sometimes be better to speak of the established aura of the artist behind the photographer himself, meaning writer and debater Ivar Lo-Johansson.

\section{The Contract-labour Photographs and the Modernisation of Sweden}

Gunnar Lundh's contract-labourer photographs are seemingly difficult to fix in time and space. Not only is there doubt as to which of the pictures from the large collection belong in this category but the photographs have also demonstrated the ability to circulate and appear both in various types of publication and for wildly differing purposes. In many cases, they have even contributed to the design of material staging and built environments. The attempt made in this article to supply the images with some of the context they lack in the museological collection has proceeded via the exploration of elements of their contemporary use and subsequent reuse. Three areas have then been deemed as especially relevant and in need of more in-depth examination: the use of the images in social reportage and 
their links to the emerging welfare state; a biographical trail; and the importance of the photographs to the construal of contract-labourers as a part of Sweden's cultural heritage.

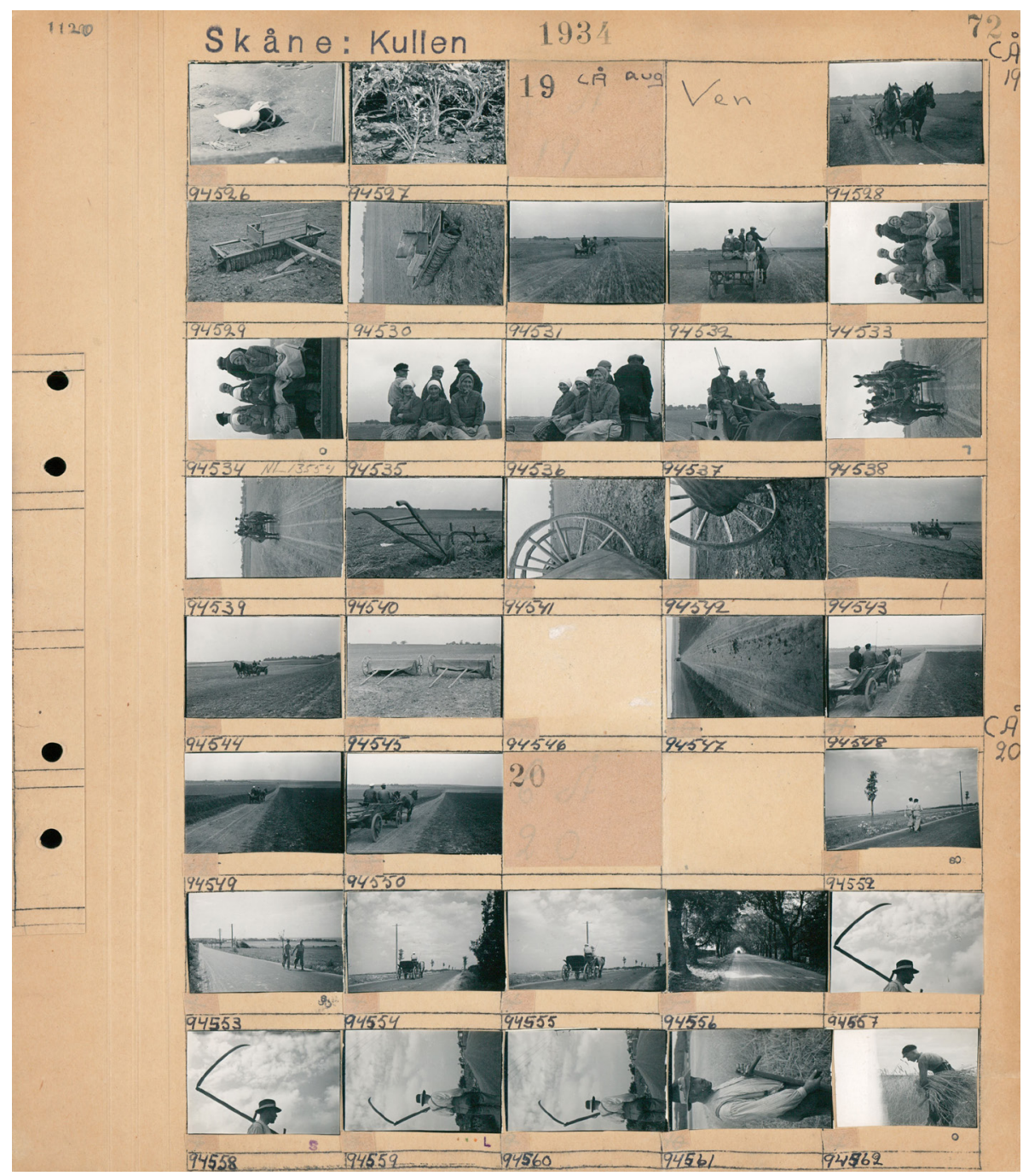

Even if these three points of entry can be viewed as distinct themes, this does not mean that they are entirely separate entities. Rather, a certain exchange is constantly taking place between the three categories. Even more, it is entirely possible to view them as tributaries of the same greater river, namely the ambition to show and document the modernisation of Sweden. Lundh's contract-labourer photographs depict the old Sweden; dirty, hierarchical, poverty-stricken and 
obsolete. This makes it an counterimage of the society we are heading towards, wish to create or believe we have already created. It is an image that offers a distinct point of departure for the narrative of an old, unworthy Sweden; a Sweden that either should be or has been consigned to history.

This forward-looking tendency is already noticeable in the 1937 photo reportage in Vi magazine, and even more so in 1948 with the publication of Statarna $i$ bild. Here, we find a common direction towards the modern, towards folkhemmet and the technological optimism that was a cornerstone of the era's reformative ideas. The contract labourer is replaced by a collective of organised and self-aware agricultural workers. The ox-which can also be read as a symbol of heavy manual labour-is replaced by the modern tractor. The earlier literary hub of the contract-labourer's home, manifested in Lundh's photograph of the shabby "alter of culture", is replaced by reading circles organised for the interested by the Workers' Educational Association and the trade union. Here, in the representation of the modern Swedish welfare state, the three tracks of the circulation of our photographs converge in the overarching presentation of past, present and future. The editors of the above-mentioned anthology, Statarna-i myt och verklighet, appear to draw similar conclusions, ending their introductory chapter by confirming that: "In the modern project, there was no room for the contract-labourers; consequently, the contract-labourer system was abolished in parallel with the Social Democrats' formulation of their post-war programme" (Lundh \& Olsson 2008:36).

Apart from Statarna i bild, Lo-Johansson did publish two other documentary photo books, Old Age (Ålderdom) (with photographers Sven Järlås and Jöran Forsslund) in 1949 and The Way of the Gypsies (Zigenarväg) (with photographer Anna Riwkin) in 1955. This group of books are often referred to as Lo-Johanssons' "social photo books" because they had a stated purpose to bring about debate, as well as to fuel social and political change. Despite the fact that all three publications received a lot of attention when they first met their audiences, it is undoubtedly the contract labour pictures that over time became mostly associated with Ivar Lo-Johansson. One likely reason for this is the circumstance that Lo-Johanssons' own authorship, as a writer of several highly valued novels, to a great extent has revolved around the contract labour theme. Still another explanation, or rather a complementary one, is that the widely-spread knowledge of the contract labour individual, or family, have become a central part of twentieth century Swedish history. Not least, has the sticky concept of the exploited contract labourer been utilised in different kinds of storytellings that wants to stress the importance of the labour movement for the modernisation of Sweden.

Nothing, however, guarantees that the temporal allegation that combine the past, present and future will remain intact forever, or everywhere. It cannot be easy for those who wander through Ivar Los' Park to grasp the political and agitational 
background of which this built environment is also an expression. Perhaps the contract-labourer photographs, too, will fade and lose their currency; perhaps all that remains will be the cows, houses and tractor-an inviting rural idyll shorn of its previous critical and historical context.

Maria Bäckman is associate professor in Ethnology at Stockholm University, department of Ethnology, Religion and Gender (ERG). This article is part of the project Images and Stories of Everyday Life (Vardagens bilder och berättelser), financed by The Royal Swedish Academy of Letters, History and Antiquities, and The Swedish Foundation for Humanities and Social Sciences. Email: Maria. backman@etnologi.su.se

\section{Notes}

1 The images in the article are, when nothing else is specified, taken from the collection of photographs by Gunnar Lundh at the Nordic Museum.

2 It is difficult to state an exact number, among other things due to the fact that Lundh himself rarely categorised his photographs with any clarity.

3 It was only ended by an agreement reached in October 1944 between the Federation of Swedish Forestry and Agricultural Employers and the Swedish Agricultural Workers' Union, which entered into force on November 11945.

4 Statistics on the number of contract labourers are taken from Statarliv-i myt och verklighet (Lundh \& Olsson, ed, 2008:14). The multivolume work Sveriges Historia (History of Sweden) states somewhat different figures. According to Yvonne Hirdman, at its peak at the end of the nineteenth century, the number of contract labourer households reached 34,000. By the time the system was abolished in 1945, the figure had decreased to 7,000 households (Hirdman 2012:57).

5 Ivar Lo-Johansson also collaborated with other photographers with regard to contract labourers; for example, a reportage in photo journal Se together with Karl Werner Gullers under the title: Statarna-Sveriges "Vredens druvor" (Contract Labourers Sweden's Grapes of Wrath) (Se 1940, no. 78, pp 20-24). Lo-Johansson has commented in another context that Gullers has a tendency to beautify his subjects, something that in depicting the living conditions of contract labourers might be perceived as unfortunate, see Lo-Johansson 1985:270.

6 In a discussion on the use of the term circulation within history-of-knowledge research, historians Johan Östling and David Larsson Heidenblad both propose in a similar manner what they call a social circulation of knowledge (2017:279f). In this context, they also emphasise the need for both a broad and inclusive concept of knowledge and concrete studies of how knowledge is used, set in motion and reconfigured (ibid: 279).

7 The Farm Security Administration (FSA) was a US Government agency created as part of President Franklin D. Roosevelt's New Deal, which led to a comprehensive expansion of the state apparatus. The FSA was specifically tasked with improving 
conditions for the country's landless, rural population, with documentary photography playing an important role in the agency's campaigns to shape public opinion. However, art historian Cecilia Strandroth (2007) emphasises that the photography programme was also part of an explicit ambition to market and legitimise the new policy. 8 Similar formulations can also be found in Lo-Johansson's own work, see, for example, the preface to Den sociala fotobildboken, 1977; Till en författare, 1988:44; as well as a longer chapter in Frihet, 1985:265.

9 Among the precursors of social reportage as a literary genre, Swedish examples include Ester Blenda Nordström's En piga bland pigor (A maid amongst maids) (1914) and Ludvig Nordström's Lortsverige (Filthy Sweden) (1938, which was also broadcast as a radio programme earlier that same year). However, none of these publications were illustrated. For a more international overview, see Nilsson (1996: 157f).

10 Folkhemmet is a political concept that entered the lexicon following a speech by Social Democrat leader Per Albin Hansson in a parliamentary debate in January 1928, in which it was used to describe the society that social democracy hoped to achieve. Source: NE.

11 Lo-Johansson also wrote a long chapter on the contract labourers in Skansen's information leaflet, Statarlängan från Berga (The Berga farm labourers' cottage), 1975. 12 There are two photographs hanging above the bed depicting an elderly man and woman. Visitors often assume that this is the Carlssons but it isn't. The man is in fact Ivar Lo-Johansson, who has thus managed to find his way into this constructed museum environment.

13 That this need not always be the case is demonstrated not only in the Carlsson's transported home in Skansen, but also by a constructed interior of a labourer household at the Utö Mining Museum, located in Stockholm's northern archipelago. This exhibit expressly takes its cue from the image of contract labourers created in proletarian literature.

14 Lo-Johansson rented two small one-room apartments at Bastugatan 21, living in one and working in the other.

15 Ivar Lo-Johansson's entry in the Dictionary of Swedish National Biography asserts that he was the first person Sträng called after the decision to abolish the contract-labour system was reached. The same story reappears in the 1995 SVT documentary Den vita piskan (The White Whip), which is available in the SVT open archive (see also Furuland 1976:192f.)

\section{References}

Magazines and newspapers

Vi, no. 471937.

Se, no. 781940.

Folket $i$ Bild, no. 31975.

Svenska Dagbladet 23.09.1948. 


\section{Culture Unbound}

Journal of Current Cultural Research

\section{Internet Sources}

Gunnar Lundh: Dictionary of Swedish National Biography https://sok.riksarkivet.se/ sbl/Presentation. aspx?id=9848 (visited 07.12.2018)

Gunnar Sträng: Dictionary of Swedish National Biography

https://sok.riksarkivet.se/Sbl/Presentation.aspx?id=34558 (visited 07.12.2018)

https://sv.wikipedia.org/wiki/Semester (visited 24.08.2019)

\section{Literature}

Andén-Papadopoulos, Kari (2008): "Medievetenskapens döda vinkel. Från pantextualism till visuell mediekultur". Solveig Jülich, Patrik Lundell \& Pelle Snickars (eds.): Mediernas kulturhistoria. Stockholm: Statens ljud och bildarkiv, 293-317.

Appadurai, Arjun (ed.) (1988): The Social Life of Things. Commodities in Cultural Perspective. Cambridge: Cambridge University Press.

Aronsson, Peter (2004): Historiebruk. Att använda detförflutna. Lund: Studentlitteratur.

Barthes, Roland (2007 [1970]): Mytologier. Lund: Arkiv.

Berg, Gösta (1975): "Förord till första upplagan”. Ivar Lo-Johansson, Mats Janson \& Ingemar Liman (eds.): Statarlängan från Berga. Skrifter från Skansen 5, Stockholm, 4-5.

Czarniawska, Barbara (2007): Shadowing and Other Techniques for Doing Fieldwork in Modern Societies. Malmö: Liber

Cronqvist, Marie, Patrik Lundell \& Pelle Snickars (2014). "Inledning". Marie Cronqvist, Patrik Lundell \& Pelle Snickars (eds.): Åter-kopplingar. Lund: Mediehistoria, Lunds universitet, 9-30.

Dahlman, Eva (1993): "Kort om kort-om museernas insamling och urval av fotografier". Adomus-nytt, no. 151993.

Ekström, Anders (2004): "Vetenskaperna, medierna och publikerna". Anders Ekström (ed.): Den mediala vetenskapen. Nora: Nya Doxa, 9-31.

Ekström, Anders (2008): "Kulturhistorisk medieforskning: Fyra spår". Solveig Jülich, Patrik Lundell \& Pelle Snickars (eds.): Mediernas kulturhistoria. Stockholm: Statens ljud och bildarkiv, 31-45.

Furuland, Lars (1975): Statare. Statarklassens historia i ord och bild till 30-årsminnet av sista statarlasset. Stockholm: Nordiska museet.

Furuland, Lars (1976): Statarnas ombudsman i dikten. En bok om Ivar Lo-Johanssons av Lars Furuland. Stockholm: LT/Svenska lantarbetarförbundet.

Gullers, Peter (2003): "Om det dokumentära. Fotografi som fakta och föreställning". Nätverket, 2003:12, 4-16.

Gustavsson, Lotten Reinius (2013): Kongobussen kommer! Den etnografiska vandringsutställningen som ett etnografiskt medium. Lotten Gustafsson Reinius, Ylva Habel \& Solveig Jülich (eds.): Bussen är budskapet. Perspektiv på mobilitet, materialitet och modernitet. Stockholm: Kungliga biblioteket, 29-53.

Hariman, Robert \& Lucaites, John Louis (2007): No Caption Needed. Iconic Photographs, Public Culture, and Liberal Democracy. Chicago: University of Chicago Press.

Hassner, Rune (1970): Jacob A. Riis. Reporter med kamera i New Yorks slum. Stockholm: Norstedt.

Hassner, Rune (1977): Bilder för miljoner. Bildtryck och massframställda bilder från de första blockböckerna, oljetrycken och fotografierna till den moderna pressens nyhetsbilder och fotoreportage. Stockholm: Sveriges radio.

Hellspong, Mats (2004): "Statareländet. Ivar Lo-Johansson och bilden av statarna". Mats Hellspong, Karin Lindvall, Nicole Pergament \& Angela Rundquist (eds.). Herrgårdsromantik och statarelände. En studie av ideologi, kulturarv och historieanvändning. Stockholm: Carlsson, 267-316. 


\section{Culture Unbound}

Journal of Current Cultural Research

Hirdman, Yvonne 2012. "Porträtt av ett land". Yvonne Hirdman, Jenny Björkman \& Urban Lundberg (eds.): Sveriges Historia 1920-1965. Stockholm: Nordstedt, 54-82.

Jülich, Solvieg, Patrik Lundell \& Pelle Snickars (2008): “Mediernas kulturhistoria: en inledning". Solvieg Jülich, Patrik Lundell \& Pelle Snickars (eds.): Mediernas Kulturhistoria. Stockholm: Statens ljud och bildarkiv, 9-29.

Jülich, Solveig (2015): "Lennart Nilsson's A Child is born. The Many Lives of a Pregnancy Advice Book". Culture Unbound, 2015:4, 627-648.

Koivunen, Leila (2009): Visualizing Africa in Nineteenth-Century British Travel Accounts. New York: Routledge.

Latour, Bruno (1998): Artefaktens återkomst. Ett möte mellan organisationsteori och tingens sociologi. Stockholm: Nerenius \& Santérus.

Liljestrand, Jens (2018): Mannen i skogen. En biografi över Vilhelm Moberg. Stockholm: Albert Bonniers Förlag.

Lindvall, Karin (2004): "Introduktion. En tidlös symbol? Det svenska samhället och herrgårdens skiftande skepnader". Mats Hellspong, Karin Lindvall, Nicole Pergament \& Angela Rundquist (eds.): Herrgårdsromantik och statarelände. En studie av ideologi, kulturarv och historieanvändning. Stockholm: Carlsson, 11-22.

Lo-Johansson, Ivar (1975): “Om statarna”. Ivar Lo-Johansson, Mats Janson \& Ingemar Liman (eds.): Statarlängan från Berga. Skrifter från Skansen 5, Stockholm, 7-94.

Lo-Johansson, Ivar (1977): Den sociala fotobildboken. Stockholm: Rabén \& Sjögren.

Lo-Johansson, Ivar (1985): Frihet. Stockholm: Bonniers.

Lo-Johansson, Ivar (1988): Till en författare. Stockholm: Bonniers.

Lundh, Christer \& Mats Olsson (eds.) (2008): Statarna-i myt och verklighet. Hedemora/Möklinta: Gidlunds

Mintz, Sidney Wilfred (2013): Sweetness and Power. The Place of Sugar in Modern History. Johanneshov: MTM

Nilsson, Bo (1975): "Fotografen Gunnar Lundhs bildsamling". Göran Bergengren, Heidi Henriksson \& Mátyás Szabó (eds.): Sista lasset in. Studier tillägnade Albert Äskeröd 9 maj 1974. Stockholm: Nordiska museet, 93-106.

Nilsson, Bo G. (1996): Folkhemmets arbetarminnen. En undersökning av de historiska och diskursiva villkoren för svenska arbetares levnadsskildringar. Stockholm: Nordiska museet. Diss.

Nordström, Ester Blenda (1914): En piga bland pigor. Stockholm: Wahlström \& Widstrand. Nordström, Ludvig (1938): Lortsverige. Stockholm: KF Bokförlag.

Nyblom, Andreas (2014): "Ritualer vid skriftkulturens altare. Skrivbordets och arbetsrummets mediehistoria". Marie Cronqvist, Patrik Lundell \& Pelle Snickars (eds.): Ater-kopplingar. Lund: Mediehistoria, Lunds universitet, 109-134.

Oldberg, Ragnar (1964): Ivar Lo-Johansson. En bildbiografi av Ragnar Oldberg. Stockholm: Bonniers.

Reberg, Arne (2001): Ivar Lo. De utsattas reporter. Stockholm: Bilda.

Ristilammi, Per-Markku (1994): Rosengård och den svarta poesin. En studie av modern annorlundahet. Stockholm: B. Östlings bokförlag, Symposion. Diss.

Rittsel, Pär \& Rolf Söderberg (1983): Den svenska fotografins historia 1840-1940. Stockholm: Bonnier fakta.

Statarna i bild (1948): Ivar Lo-Johansson \& Gunnar Lundh. Stockholm: KF Bokförlag.

Strandroth, Cecilia (2007): In Search of the Pure Photograph. A Historiographic Study of the Farm Security Administration, Walker Evans and the Survey Histories of Photography. Uppsala: Uppsala University. Diss.

Strandroth, Cecilia (2009): "På forskningsresa i det digitala bildarkivet - ett brukarperspektiv". Anna Dahlgren \& Pelle Snickars (eds.): I bildarkivet. Om fotografi och digitaliseringens effekter. Stockholm: Kungliga Biblioteket, 91-120.

Thorbech, Åsa (1994): "Vardagsnära bilder. Om fotografen Gunnar Lundh". Tack vare våra vänner! Fataburen 1994. Nordiska museets och Skansens årsbok 1994. Stockholm: Nordiska museet, 124-141.

Östling, Johan \& David Larsson Heidenblad 2017: “Cirkulation-ett kunskapshistoriskt nyckelbegrepp”. Historisk tidskrift, 2017:2, 269-284. 